\title{
Taxonomic diversity of Biomphalaria (Planorbidae) in São Paulo state, Brazil
}

\author{
Fernanda Pires Ohlweiler $^{1 *}{ }^{\circledR}$, Thays de Jesus Rossignoli ${ }^{\circledR}$, Raquel Gardini Sanches Palasio ${ }^{2} \mathbb{\&}$ \\ Roseli Tuan ${ }^{2}$ (1) \\ ${ }^{1}$ Superintendência de Controle de Endemias, Laboratório de Malacologia da Divisão de Programas Especiais, \\ São Paulo, SP, Brasil. \\ ${ }_{2}^{2}$ Superintendência de Controle de Endemias, Laboratório de Bioquímica e Biologia Molecular, São Paulo, SP, \\ Brasil. \\ *Corresponding author: Fernanda Pires Ohlweiler, e-mail: fpohlweiler@gmail.com
}

OHLWEILER, F.P., ROSSIGNOLI, T.J., PALASIO, R.G.S., TUAN, R. Taxonomic diversity of Biomphalaria (Planorbidae) in São Paulo state, Brazil. Biota Neotropica 20(2): e20200975. https://doi.org/10.1590/16760611-BN-2020-0975

\begin{abstract}
Morphological and molecular identifications were carried out for Biomphalaria occidentalis, Biomphalaria oligoza, Biomphalaria peregrina, Biomphalaria schrammi, Biomphalaria straminea and Biomphalaria tenagophila collected from 55 sites located along the upper basin of Tietê River in the Southeast Region of Brazil. Morphological analysis considered aspects of the shell, mantle, excretory organs and reproductive system. Molecular data included 122 sequences of Cytochrome C Oxidase I gene (COI). Our results showed that some shell characters, as well as other characters related to the mantle and the reproductive system, are fundamental for the identification of the six Biomphalaria species included in this study. The use of DNA barcoding together with morphological taxonomy generated more reliable results, proving to be a very useful approach, even for malacological surveillance services. Keywords: COI; DNA Barcoding; Morphology; Schistosomiasis; Intermediate Host Snail.
\end{abstract}

\section{Diversidade taxonômica de Biomphalaria (Planorbidae) no estado de São Paulo, Brasil}

Resumo: Foi realizado estudo morfológico e molecular de Biomphalaria occidentalis, B. oligoza, B. peregrina, $B$. schrammi, B. straminea e B. tenagophila coletados em 55 pontos situados ao longo da bacia hidrográfica do Alto Rio Tietê a sudoeste do Brasil. A análise morfológica levou em consideração aspectos da concha, manto, órgãos excretores e sistema reprodutor. Os dados moleculares incluíram 122 sequências do gene mitocondrial Citocromo C Oxidase I (COI). Nossos resultados mostram que alguns caracteres da concha, bem como outros relacionados ao manto e ao sistema reprodutor foram aqui considerados fundamentais na determinação das seis Biomphalaria tratadas neste estudo. A utilização do DNA Barcode simultaneamente com a taxonomia morfológica gerou resultados mais fidedignos, demonstrando ser uma abordagem bastante útil, inclusive, para os serviços de vigilância malacológica. Palavras-chave: COI; DNA Barcode; Morfologia; Esquistossomose; Caramujos Hospedeiros Intermediários.

\section{Introduction}

Schistosomiasis is a neglected disease that affects regions with precarious sanitary infrastructure, such as those found in endemic areas of Brazil (Baracho 2013). The transmission of schistosomiasis is closely linked to a population's contact with freshwater and the presence of mollusks of the genus Biomphalaria Preston, 1910, which host trematode larvae of Schistosoma mansoni Sambon, 1907, the etiological agent of schistosomiasis.

The planorbid chart of the metropolitan region of São Paulo, presented by Piza et al. (1972) and Ohlweiler \& Rossignoli (2016), indicate the presence of Biomphalaria occidentalis Paraense, 1981, Biomphalaria oligoza Paraense, 1975, Biomphalaria peregrina (d'Orbigny, 1835), Biomphalaria schrammi (Crosse, 1846), Biomphalaria straminea (Dunker, 1848) and Biomphalaria tenagophila (d'Orbigny, 1835) in water bodies of the upper basin of Tietê River in state of São Paulo, located in the southeast of Brazil. Biomphalaria straminea and B. tenagophila were naturally found infected with $S$. mansoni in Brazil (Ohlweiler et al. 2010). Biomphalaria straminea is widely geographically distributed in Brazil, especially in northeastern states, where it is an important intermediary host of $S$. mansoni (Figueiredo 1989, Ohlweiler et al. 2010). Biomphalaria tenagophila, albeit it presents low rates of $S$. mansoni infection both in the field and in the laboratory, is responsible for the schistosomiasis outbreaks in the state of São Paulo (Paraense \& Corrêa 1978).

The risk of schistosomiasis expansion in the upper basin of Tietê River is notorious in view of the presence of $B$. tenagophila in its hydrographic complex. Studies involving morphological and molecular identification of Biomphalaria occurring in the upper basin of Tietê River are extremely important for defining areas that are prone to schistosomiasis, as well as for understanding disease transmission in the region.

The morphological identification of Biomphalaria is carried out based on anatomical characters especially of the reproductive system 
and renal tube (Paraense 1966a, 1975). However, phenotypic plasticity has been reported in Biomphalaria by Paraense (1966a, 1974, 1975, 1988), Paraense \& Deslandes (1962), Spatz et al. (1999), Caldeira et al. (2000), Vidigal et al. (2000a, b), Carvalho et al. (2008) and Silva (2012).

The classification of Biomphalaria based on morphological characters presents difficulties in determining discrete taxonomic units, such as subspecies and the cryptic species that form complexes. For Biomphalaria, the tenagophila species complex (B. tenagophila, $B$. tenagophila guaibensis Paraense, 1984 and B. occidentalis) (Spatz et al. 1999) and straminea species complex (B. straminea, B. kuhniana (Clessin, 1883) and B. intermedia (Paraense \& Deslandes, 1962) (Paraense 1988) are described. Aside from these two complexes, other Biomphalaria species, also registered in Brazil, have very similar characteristics to each other, such as $B$. peregrina and $B$. oligoza (Paraense 1974, 1975), and B. cousini Paraense, 1966 and B. amazonica Paraense, 1966 (Paraense 1966b).

In Neotropical gastropod groups, Cytochrome C Oxidase I (COI) helps to identify morphologically similar taxa and cryptic species (Tuan et al. 2012, Collado et al. 2016, Palasio et al. 2017). However, no molecular method should be applied in the taxonomic classification of Biomphalaria without support of morphological analysis, given that the anatomical characters are still the gold standard for identifying Biomphalaria at the species level.

This paper aims to understand the biodiversity of Biomphalaria in floodplain areas of the upper basin of Tietê River, in order to determine the extent of $S$. mansoni transmission risk areas. For this purpose, morphological and molecular identification methods were applied to Biomphalaria snails collected in freshwater bodies associated with the upper basin of Tietê River.

\section{Materials and Methods}

Planorbid snails of the genus Biomphalaria were collected from 55 points in freshwater bodies located along a $5,720 \mathrm{Km}^{2}$ line of the upper basin of Tietê River, in 18 municipalities of São Paulo (Brazil), from September 2015 to July 2016 (Figure 1 and Table 1).

Geocoding of collection points and elaboration of illustrative distribution maps of Biomphalaria in the upper basin of Tietê River were carried out in the program QGIS version 3.4.11 (QGIS 2019) using the coordinates of the georeferenced localities (latitude/longitude). The data referring to the geographic coordinates of the collection points were obtained through the Global Positioning System (GPS) Garmin

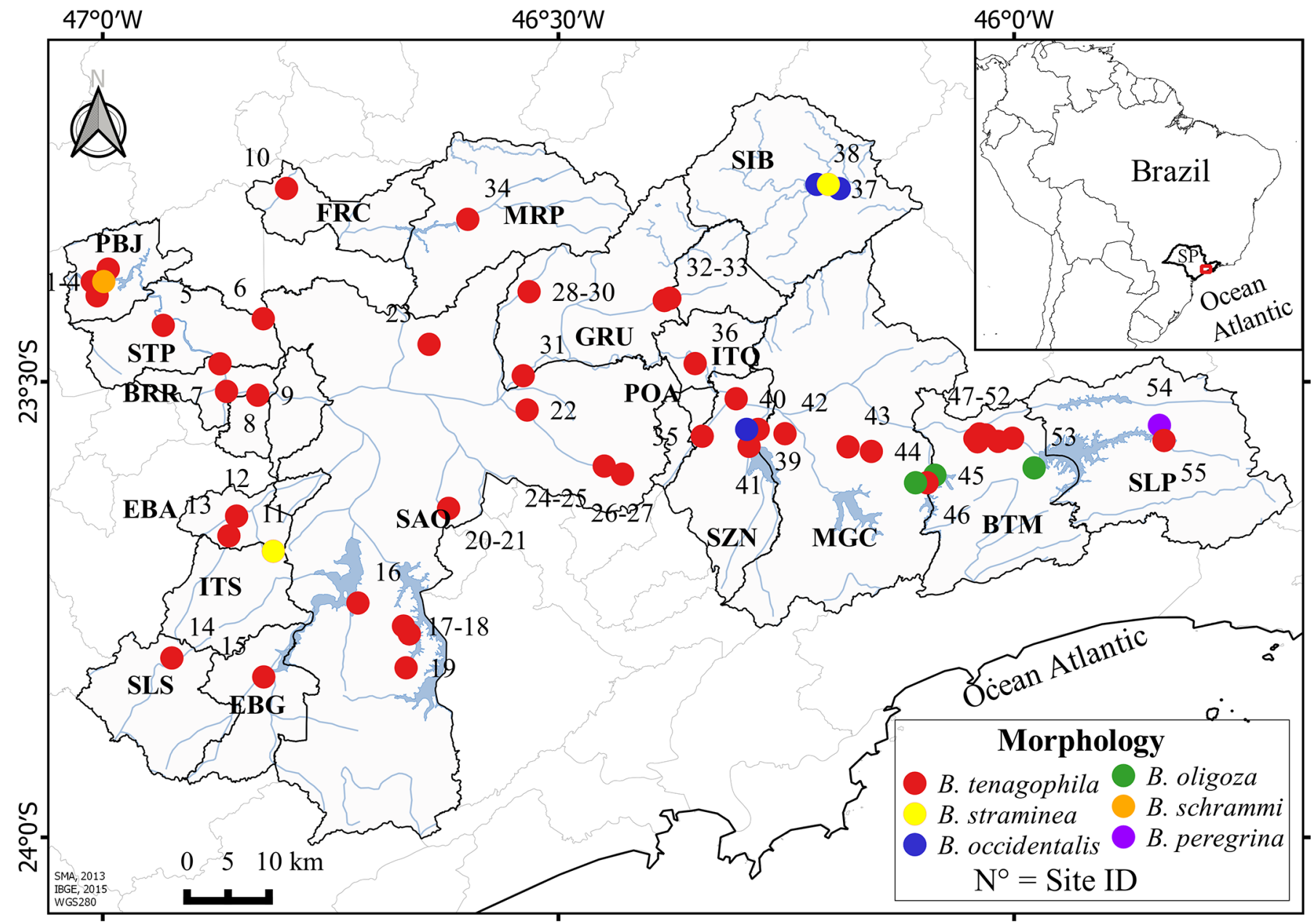

Figure 1. Maps of the distribution of Biomphalaria spp. collected in the Upper Tietê River Basin, São Paulo/Brazil. BRR, Barueri; BTM, Biritiba Mirim; EBA, Embú das Artes; EBG, Embu Guaçu; FRC, Franco da Rocha; GRU, Guarulhos; ITQ, Itaquaquecetuba; ITS, Itapecerica da Serra; MGC, Mogi das Cruzes; MRP, Mairiporã; PBJ, Pirapora do Bom Jesus; POA, Poá; SAO, São Paulo; SIB, Santa Isabel; SLP, Salesópolis; SLS, São Lourenço da Serra; STP, Santana de Parnaíba; SZN, Suzano;*, Codes of collection points (Site ID) in Table 1. 
Table 1. Biomphalaria collected in municipalities of the Upper Tietê River Basin, São Paulo/Br and Genbank access numbers for $122 \mathrm{COI}$ sequences used in this study.

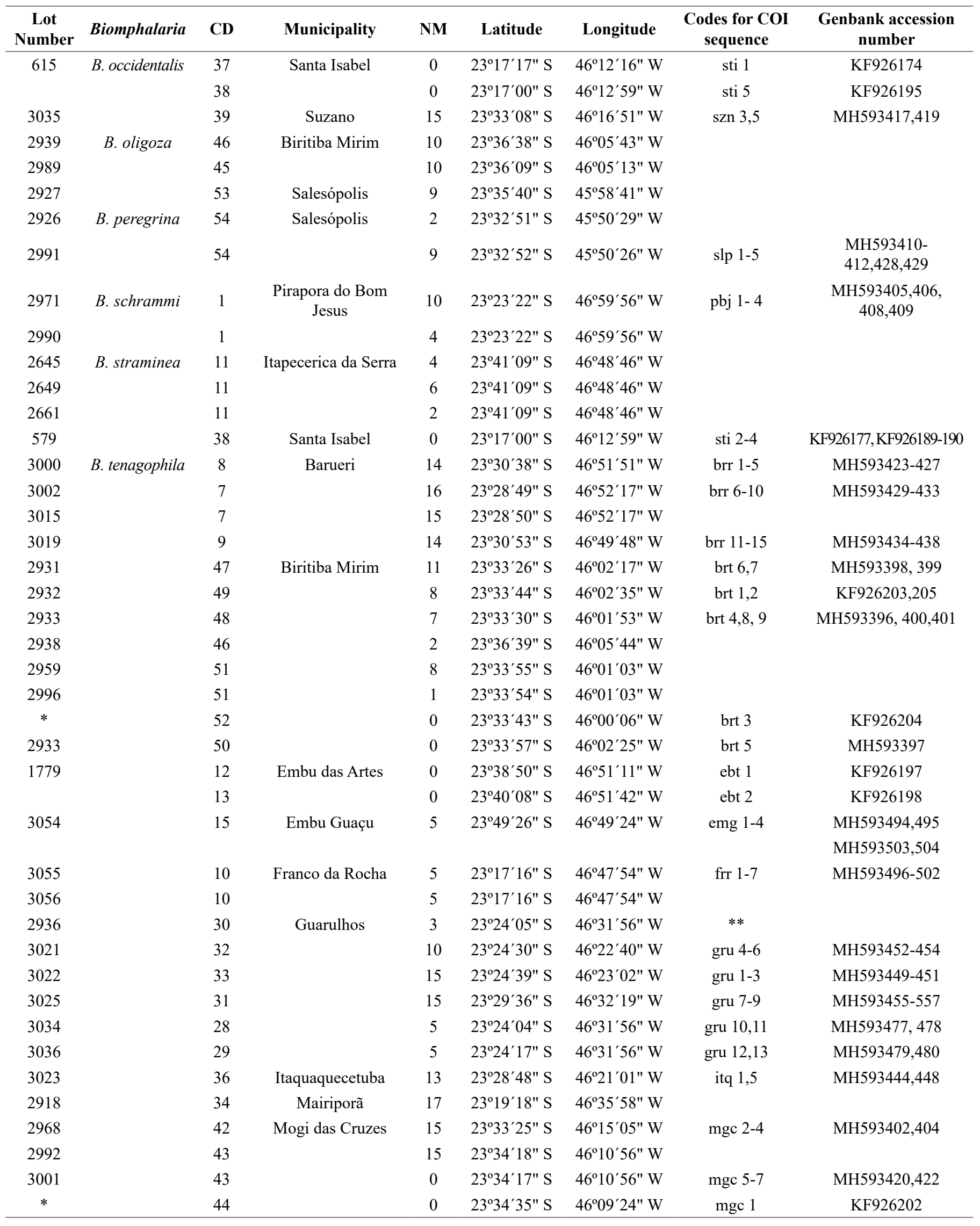




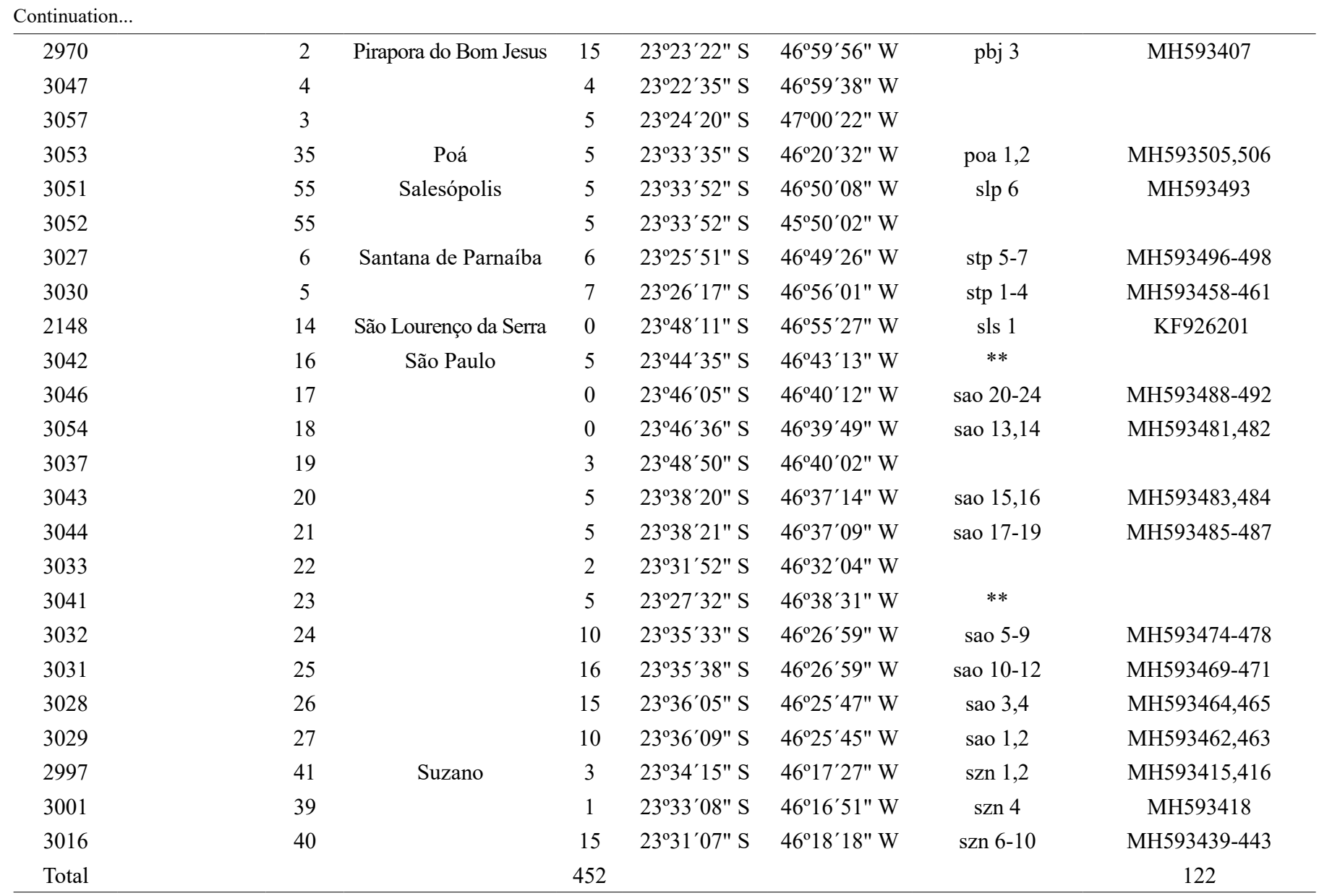

*; COI sequences, from the Molecular Biology Laboratory of SUCEN, of malacological material not included in the collection of the Divisão de Programas Especiais (DPE) of SUCEN, **; species without COI sequences, CD; Code of the numbers of the collection sites in Figure 1, NM; Number of specimens used in the morphological study.

Etrex 10. The cartographic materials were collected from the web sites of the Instituto Brasileiro de Geografia e Estatística (IBGE 2015) and Secretaria de Meio Ambiente do Estado de São Paulo (SMA 2013).

Snails were collected manually with tweezers and a perforated metal ladle attached to a wooden handle, according to the technique used during the Schistosomiasis Surveillance and Control Program by the Ministry of Health (Brasil 2008). To standardize the samples, collections lasted for 1 hour at each collection point, with a sampling effort of three collectors (Brasil 2008).

In the laboratory, the live snails were subjected to parasitological examination by exposure to artificial light for up to 4 hours, to verify if they were infected with trematodes larvae (Ohlweiler et al. 2013). Infection free snails with intact anatomical structures were used in the morphological and molecular study.

The morphological and molecular study was performed on healthy snails free from parasite larvae, which were anesthetized with menthol crystals for 24 to 48 hours at a temperature of $4^{\circ} \mathrm{C}$. Afterwards, their bodies were separated from their shells according to the methodology described by the Ministry of Health (Brasil 2008).

\section{Morphological study}

Snail bodies were fixed for at least 48 hours in a Railliet-Henry solution, where they were kept permanently, and the shells were dry conditioned. The morphological analyses are based on 35 characters: 10 related to the shell, 2 to the mantle, 3 to the excretory system and 20 to the reproductive system. A minimum of 11 adult specimens were analyzed per species under a stereoscopic microscope, according to the available bibliography. The shells were measured with a DE MEO analogue caliper with scale in millimeters $(0.05 \mathrm{~mm})$.

\section{Molecular Study}

The mitochondrial DNA segment corresponding to the COI gene was amplified using the primers LCO1498 and HCO2190 (Folmer et al. 1994), which allow the 658 bp-region of the COI gene to be amplified (Hebert 2003). At least one snail from each sampled site was used for molecular identification, except for Mairiporã and Itapecerica da Serra, as DNA extraction was not possible for such material. The morphology of specimens used for molecular identification were previously identified (Table 1). In the PCR-COI amplification reaction, $25 \mu 1$ of Master Mix solution, $2 \mu \mathrm{l}$ of $0.1 \mu \mathrm{M}$ of each Primer (HCO and LCO), $2 \mu \mathrm{l}$ of 10-100 ng of DNA, and $19 \mu \mathrm{l}$ of water were used. Amplifications (Biometra Thermo Cycler) were performed according to the following protocol: $95^{\circ} \mathrm{C}$ for 3 minutes; 25 cycles of $95^{\circ} \mathrm{C}$ for 1 minute, $47^{\circ} \mathrm{C}$ for 1 minute and $72^{\circ} \mathrm{C}$ for 1 minute and 30 seconds.

Samples with at least $20 \mathrm{ng}$ of $\mathrm{DNA} / \mu \mathrm{L}$ were sequenced. Sequencing reactions were made in an ABI 3100 automatic sequencer 
(Applied Byosistems ${ }^{\circledR}$ ) at the Molecular Biology Laboratory in the Biotechnology Center at the Butantan Institute.

The sequences were aligned using MAFFT version 7 (Katoh et al. 2017) under the Q-INS-I parameter to restrict the formation of gaps. The aligned sequences were visually corrected in BioEdit 7.2.5 (Hall 1999) and individually analyzed in the NCBI (2018) using Basic Local Alignment Search Tool - Nucleotídeo (BLASTn) (Benson et al. 2012) data base to obtain the highest similarity values between the target sequence and the sequences previously deposited in the GenBank ${ }^{\circledR}$. The values of interspecific and intraspecific genetic divergence by distance matrix were generated in MEGA X (Kumar et al. 2018). Genetic polymorphism indexes were calculated using the software DnaSP version 6.12 (Rozas et al. 2017).

For the phylogenetic analysis, a known sequence of the North American snail Planorbella trivolvis (Say, 1817) was used as the out group (Genbank accession number MG4229211). The Model generator program (Keane et al. 2006) was used to determine the most suitable nucleotide substitution model for the sequences submitted to phylogenetic analysis based on ML (Maximum likelihood) in the program PhyML 3.2 (Guindon \& Gascuel 2003). The reliability values of the tree branches were obtained using a LRT (Approximate Likelihood Ratio Test) associated with non-parametric correction based on the Shimodaira-Hasegawa (SH) algorithm for tree comparison (Shimodaira \& Hasegawa 1999, Anisimova et al. 2011).

For analysis of species delimitation methods in molecular operational taxonomic units (MOTUs), the following statistical tests were applied: A) ABGD (Automatic Barcode Gap Discovery) (Puillandre et al. 2012), which considers distances as parameters to infer Barcoding gaps; B) bPTP (Zhang et al. 2013), which calculates the highest probability of branches through Bayesian analysis. The file containing the tree data calculated under ML, GTR $+\mathrm{G}+\mathrm{I}$ as an evolutionary model, was used for the calculations in bPTP (Zhang et al. 2013). C) GMYC (General mixed Yule Coalescent) (Fujisawa \& Barraclough 2013), which uses speciation models (interspecific relations) and coalescence (intraspecific relations) to infer identified species. The $\mathrm{GTR}+\mathrm{G}+\mathrm{I}$ evolution model was used as the basis of calculation for the construction of an ultrametric tree in MEGA X (Kumar et al. 2018), which served as input file for calculating the cluster number (Zhang 2015).

The 112 sequences obtained in this study were deposited in GenBank, with accession number MH593395 to MH593506. We also used other 12 sequences (Palasio et al. 2017) deposited in GenBank under the not consecutive accession numbers KF926174 to KF926204, as described in Table 1. The vouchers, along with the snails used for the morphological study, were catalogued according to their collection sites and deposited in the Malacological Collection at the Division of Special Programs of the Superintendence of Control of Endemic Diseases of the State of São Paulo - SUCEN under the numbers DPE1779 to DPE3057 (not necessarily consecutive) (Table 1).

\section{Results}

\section{Morphological study}

The 35 morphological characters observed in the 452 snails Biomphalaria (15 specimens of Biomphalaria occidentalis, 29 Biomphalaria oligoza, 11 Biomphalaria peregrina, 14 Biomphalaria schrammi, 12 Biomphalaria straminea and 371 Biomphalaria tenagophila) are presented in the Tables 2 and 3.

Morphological analysis shows that 26 out of the 35 characters examined indicate significant anatomical differences among the six species of Biomphalaria: five shell characters - shape of the turns, carenas, internal lamellas on the last turn of the shell, opening shape and opening position - two of the mantle - pattern of mantle pigmentation and stain pattern - and nineteen reproductive system

Table 2. Morphological characters of the shell of Biomphalaria from the Upper Tietê River Basin, São Paulo-Brazil.

\begin{tabular}{|c|c|c|c|c|c|c|}
\hline Shell characters & B. tenagophila & B. occidentalis & B. oligoza & B. peregrina & B. schrammi & B. straminea \\
\hline Color & Brown & Brown & Brown & Brown & Brown & Brown \\
\hline \multicolumn{7}{|l|}{ Diameter (mm) } \\
\hline Minimum-Maximum & $3,4-22,5$ & $6,2-13,6$ & $3,3-5,2$ & $6,2-8,4$ & $4,6-5,4$ & $5,2-7,0$ \\
\hline \multicolumn{7}{|l|}{ Width (mm) } \\
\hline Number of turns & $41 / 4$ to 7 & 5 to $61 / 4$ & 4 to $41 / 2$ & $41 / 4$ to $41 / 2$ & 4 to $43 / 4$ & $41 / 2$ to 5 \\
\hline Aspect of sutures & Defined & Defined & Well defined & Defined & Well defined & Well defined \\
\hline Shape of the turns* & Angular & Angular & Rounded & Rounded & Rounded & Rounded \\
\hline Carenas* & Present & Present & Absent & Absent & Absent & Absent \\
\hline Opening position* & Front & Front & Front & $\begin{array}{l}\text { Lightly deflected } \\
\text { to the left }\end{array}$ & $\begin{array}{c}\text { Heavily deflected } \\
\text { to the left }\end{array}$ & $\begin{array}{l}\text { Lightly deflected } \\
\text { to the left }\end{array}$ \\
\hline
\end{tabular}

*morphological characters with expressive anatomical characteristics 
Table 3. Morphological characters of the mantle, excretory system and reproductive system of Biomphalaria from the Upper Tietê River Basin, São Paulo/Brazil.

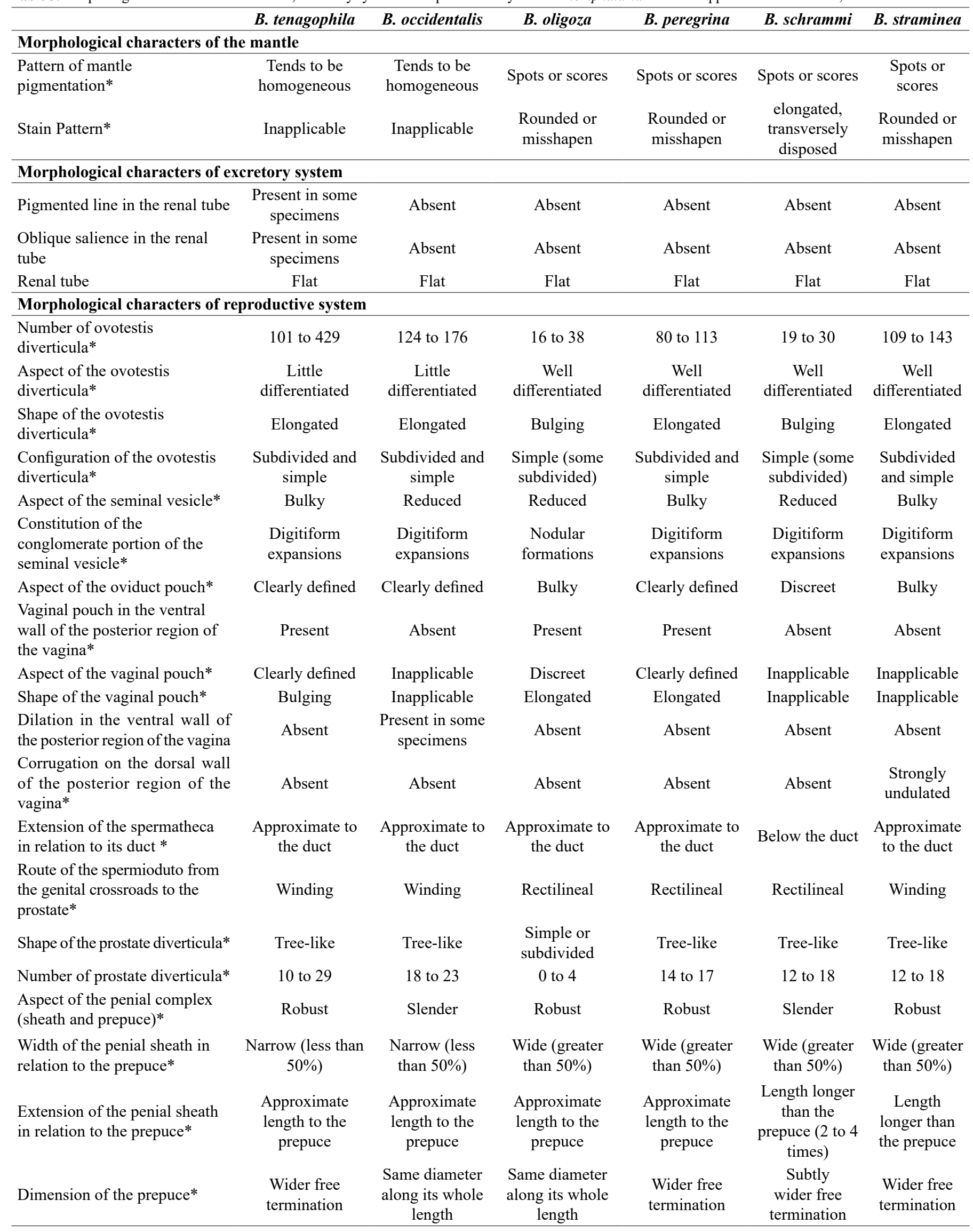

*morphological characters with expressive anatomical characteristics 
(Tables 2 and 3, Figures 2 to 8, Appendix 1 and 2). The morphological differences found in the reproductive system are related to the following structures: ovotestis diverticula, seminal vesicle, oviduct pouch, vaginal pouch, vaginal corrugation, spermatheca duct, spermatheca, spermiduct, prostate diverticula and penial complex.

Some of the morphological characters are intrinsic to four out of the six species studied, which are from Biomphalaria oligoza (Figures 4 and 6): 1- conglomeration portion of the seminal vesicle consisting of nodular formations, 2- discrete aspect of the vaginal pouch, 3- simple prostate diverticula, bifurcated or trifurcated and 4- reduced number of prostate diverticula; Biomphalaria schrammi (Appendix 1, Figures 2 and 6): 1- presence of internal lamellae on the last suture of the shell, 2- opening of the shell strongly reflected to the left, 3- elongated and transversely arranged stains on the mantle, 4- discrete aspect of the oviduct pouch, 5- spermatheca with inferior extension to the duct; Biomphalaria tenagophila (Figure 8): 1- bulging shape of the vaginal pouch; Biomphalaria straminea (Figure 5): 1- strongly undulated corrugation on the dorsal wall of the posterior region of the vagina. Biomphalaria peregrina and B. occidentalis have important characters in the specific determination, which are not necessarily inherent in each one of them (Tables 2 and 3 ).

A larger number of morphological characters, with expressive anatomical specificities, are shared exclusively among species of pairs $B$.

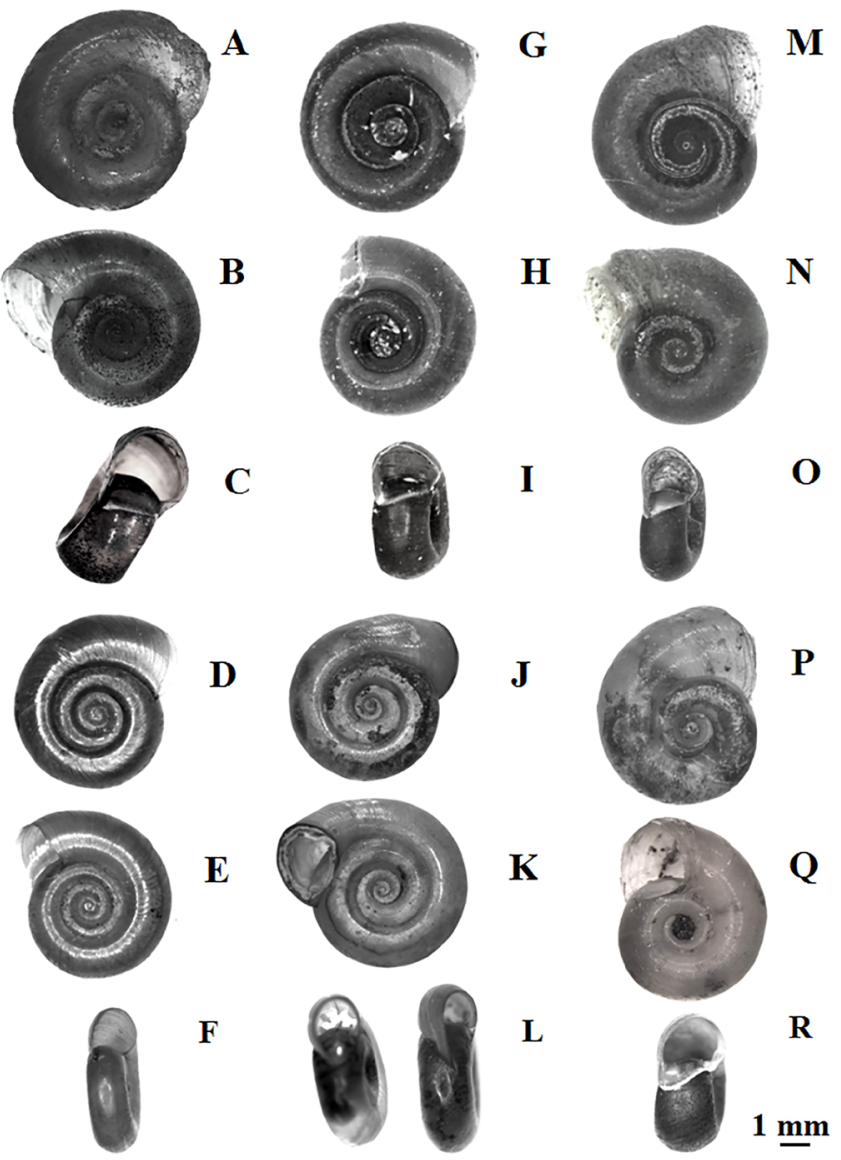

Figure 2. Right lateral views, left and front of shells of the Biomphalaria spp. A-C, Biomphalaria tenagophila; D-F, Biomphalaria peregrina; G-I, Biomphalaria occidentalis; J-L, Biomphalaria schrammi; M-O, Biomphalaria oligoza; P-R, Biomphalaria straminea.
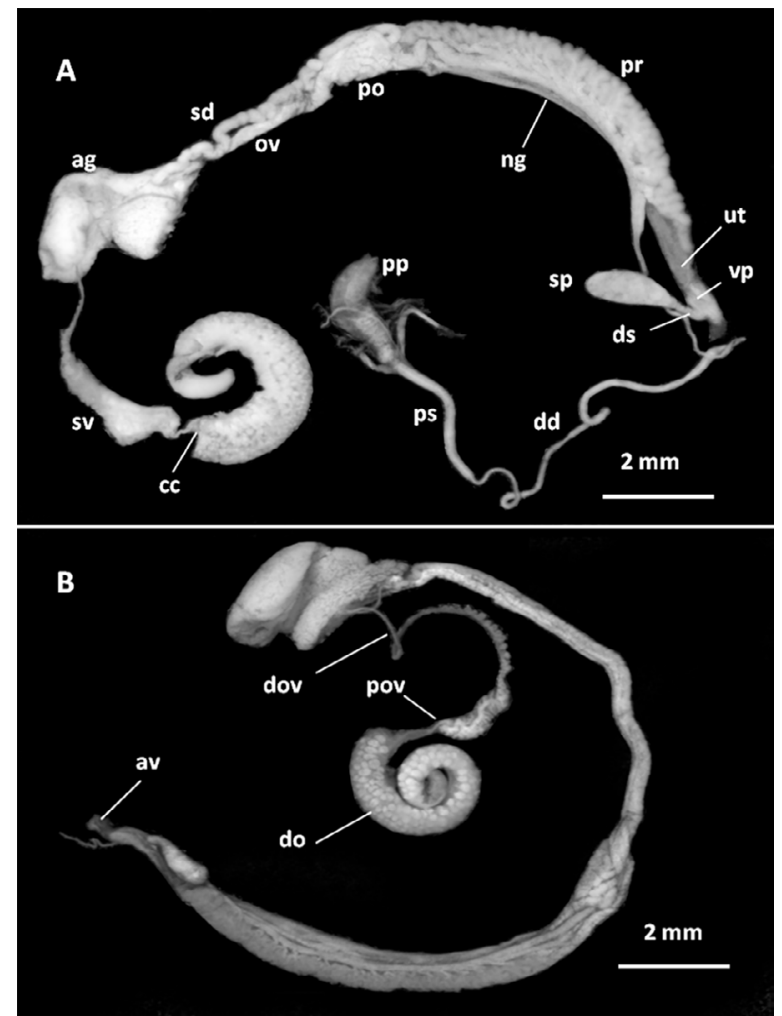

Figure 3. Genital organs. A, Biomphalaria tenagophila; B, Biomphalaria occidentalis; ag, albumen gland; av, anterior vagina; $\mathrm{cc}$, free portion of the collector channel; dd, duct deferens; do, diverticula of ovotestis; dov, distal ovispermiduct; ds, duct of spermatheca; ng, nidamental gland; ov, oviduct; po, pouch of oviduct; pov, proximal ovispermiduct; pp, prepuce; pr, prostate; ps, penial sheath; sd, spermiduct; sp, spermatheca; sv, seminal vesicle; ut, uterus; vp, vaginal pouch.
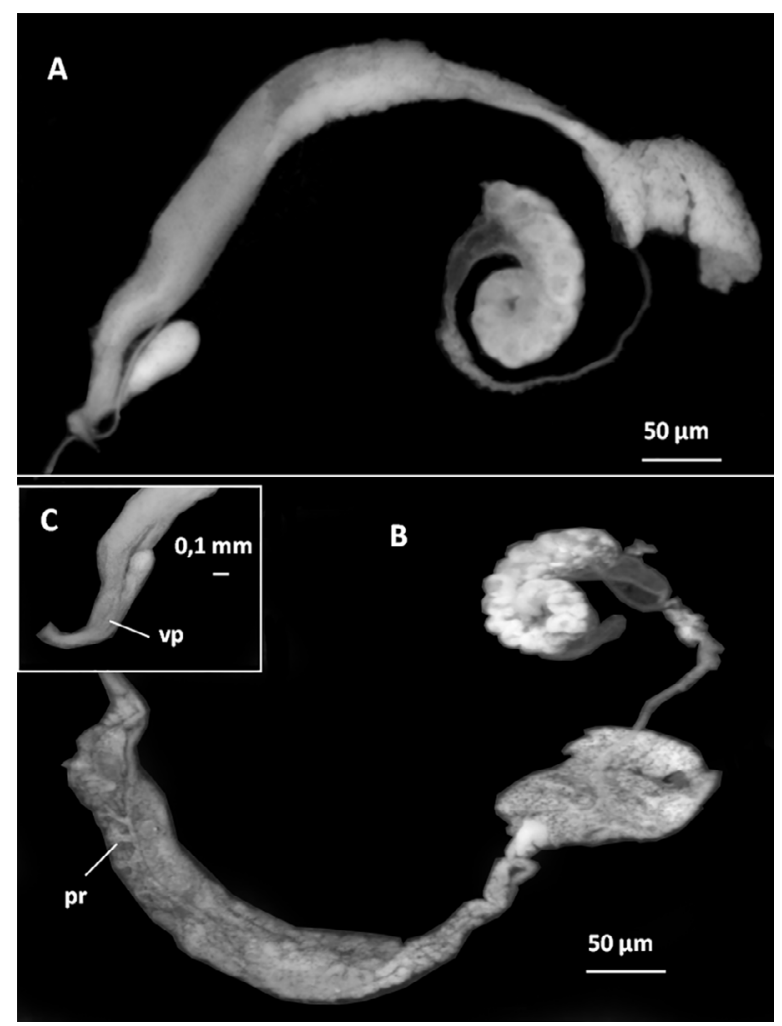

Figure 4. Biomphalaria oligoza. A and B, genital organs; $\mathrm{C}$, detail of the vagina showing the vaginal pouch; vp, vaginal pouch; pr, prostate. 

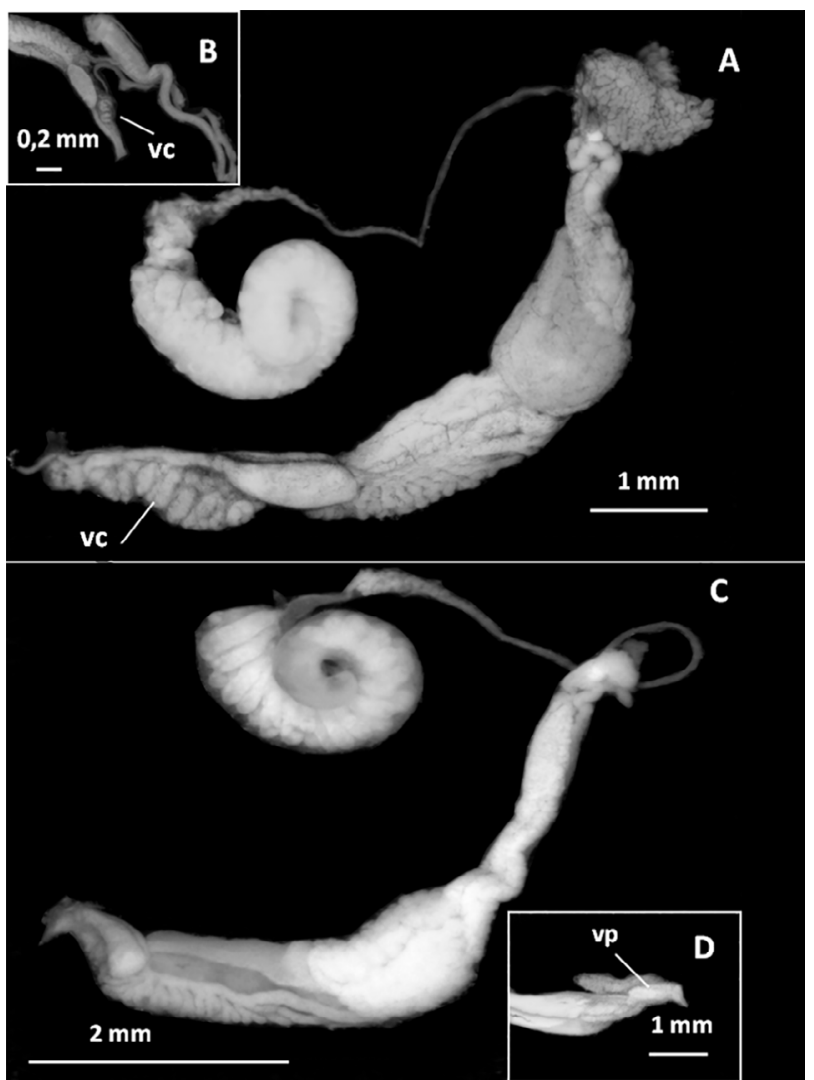

Figure 5. Genital organs. A and B, Biomphalaria straminea with detail of the vagina region showing corrugation; $\mathrm{C}$ and $\mathrm{D}$, Biomphalaria peregrina with detail of the vagina showing the vaginal pouch; vc, vaginal corrugation; vp, vaginal pouch. Absent or partially absent albumen gland in both figures.

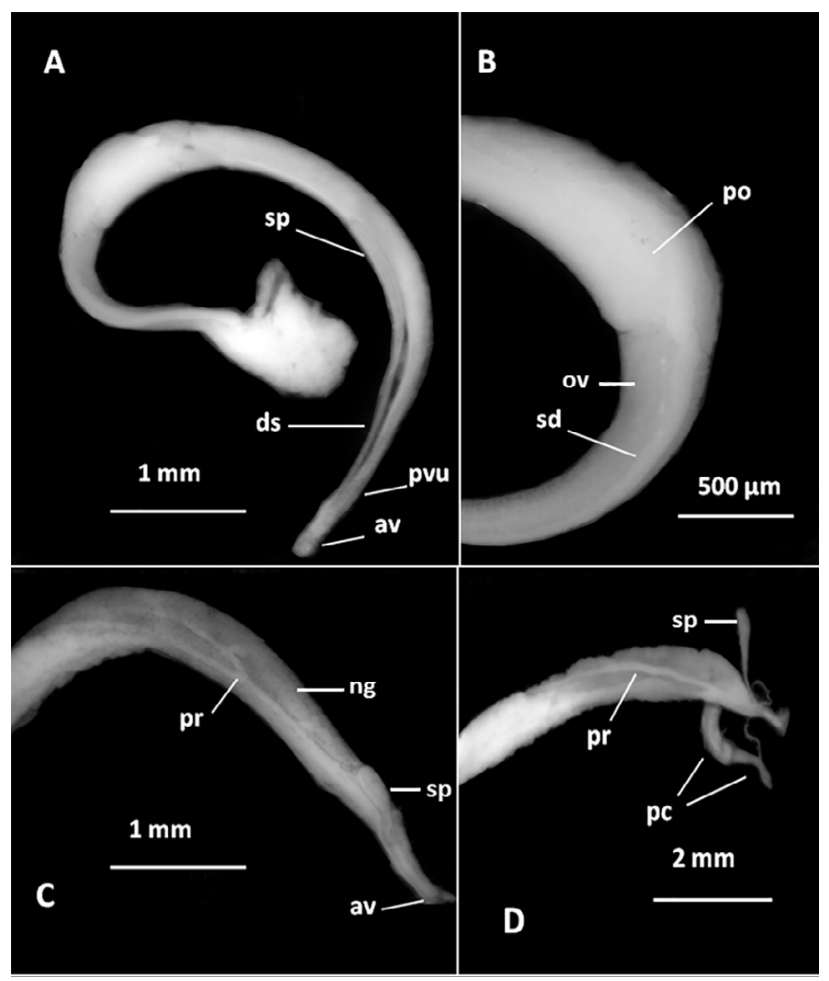

Figure 6. Genital organs. A and B, Biomphalaria schrammi; C and D, Biomphalaria oligoza; av, anterior vagina; ds, duct of spermatheca; ng, nidamental gland; ov, oviduct; pc, penial complex; po, pouch of oviduct; pr, prostate; pvu, region of the posterior vagina and uterus; sd, spermiduct; sp, spermatheca.

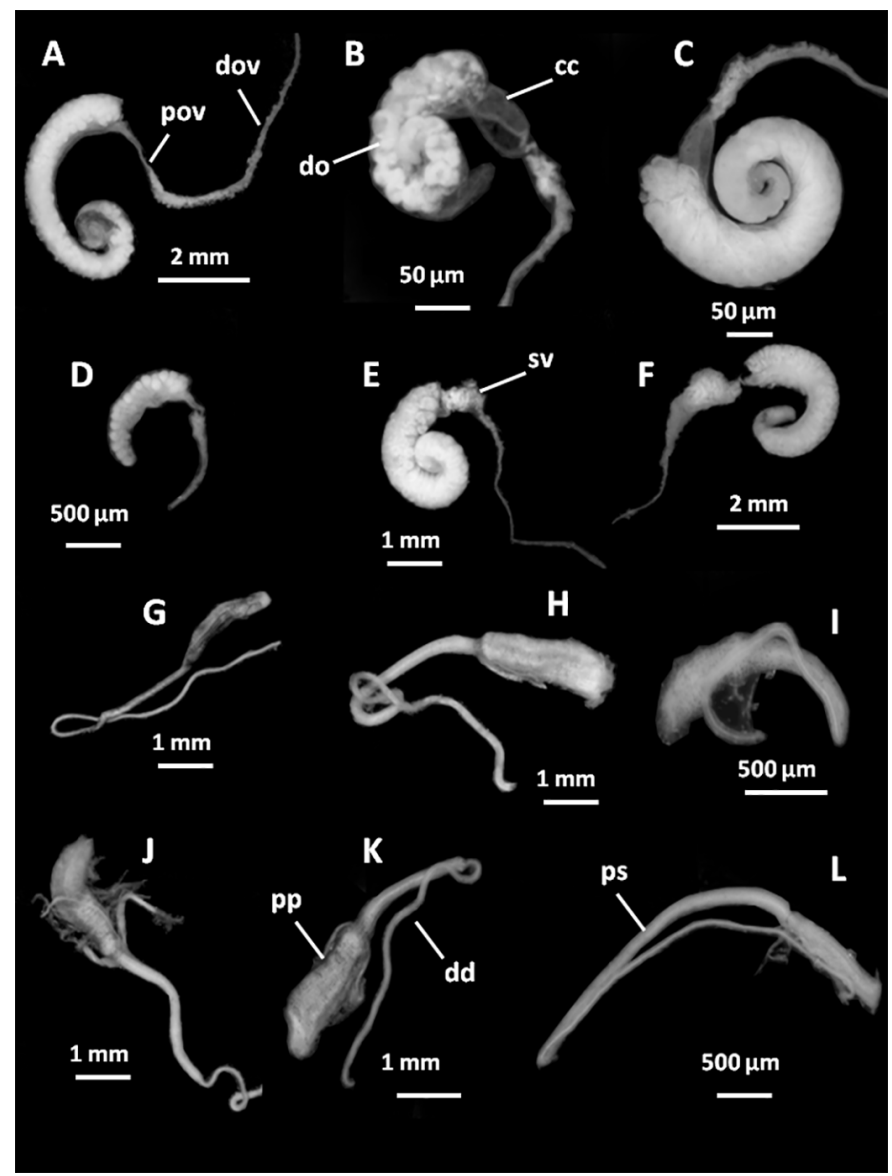

Figure 7. Ovotestis (A to F) and penial complex (G to L). A and G, Biomphalaria occidentalis; $\mathrm{B}$ and I, Biomphalaria oligoza; $\mathrm{C}$ and $\mathrm{K}$, Biomphalaria peregrina; $\mathrm{D}$ and L, Biomphalaria schrammi; $\mathrm{E}$ and $\mathrm{H}$, Biomphalaria straminea; F and J, Biomphalaria tenagophila; $\mathrm{cc}$, free portion of the collector channel; dd, duct deferens; do, diverticula of ovotestis; dov, distal ovispermiduct; pp, prepuce; ps, penial sheath; pov, proximal ovispermiduct; sv, seminal vesicle.

tenagophila vs B. occidentalis (6/26) and B. oligoza vs B. schrammi (3/26) (Table 4). The other pairs of species share one or none morphological character with significant anatomical specificity (Table 4).

\section{Molecular analysis}

Molecular data consisted of an alignment of $567 \mathrm{pb}$ of 124 specimens derived from the study area. The 122 COI sequences obtained in this study are presented in Table 1. Molecular results do not include two sequences of $B$. oligoza, due to the low quality of the sequences resulting from the amplification of genomic DNA with the COI-Folmer primers.

The number of COI sequences of the species reflects directly their population size in the study region. The total genetic variation in the set of 122 COI sequences is $3.0 \%$, due to the genetic polymorphism in $B$. tenagophila and $B$. straminea, each species with $1.0 \%$ genetic variation (Table 5). Although low, the value obtained for B. tenagophila and $B$. straminea contrasts with null values obtained from sequences related to the species B. occidentalis, B. peregrina and B. schrammi, in which no intraspecific genetic variations were observed (Table 5).

The lowest interspecific genetic divergence values were observed in the B. tenagophila and B. occidentalis (5\%) (Table 6), a pair of species which belongs to a species complex. In pair of species with 


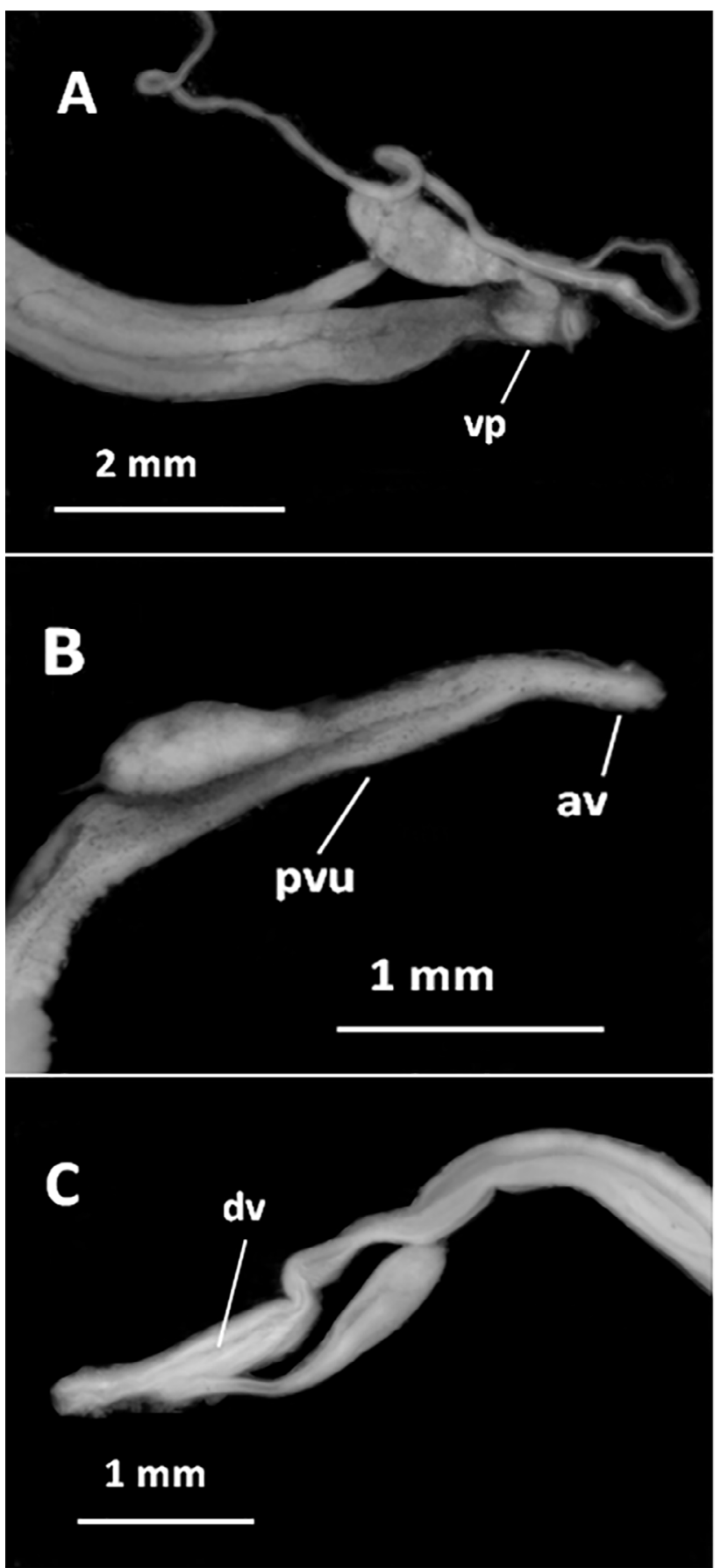

Figure 8. Region of the vagina. A, Biomphalaria tenagophila; B and C, Biomphalaria occidentalis; av, anterior vagina; dv, dilation of the vagina; pvu, region of the posterior vagina and uterus; vp, vaginal pouch. high dissimilar morphology, the interspecific values vary from $9 \%$ to $13 \%$.

Table 7 shows the results obtained through the analysis of the sequences in ABGD, bPTP and GMYC. The highest values of similarity indices between sequences of this study and sequences found in the Genbank correspond to the sequences of the specimens identified as $B$. tenagophila, $B$. straminea, and $B$. occidentalis. The similarity values between $97-98 \%$ were observed in the sequences from species identified as $B$. peregrina. A group of four sequences, whose specimens were identified as B. schrammi, showed lower similarity value (Table 7).

The results of the analysis of COI sequences by sequence delimitation methods in taxonomic units are the following:

For the range of intraspecific genetic divergence values (ABDG) of 0.013-0.021 there is high statistical probability of partitioning for 122 sequences in five groups of putative species (Group 1: B. tenagophila, Group 2: B. occidentalis, Group 3: B. straminea, Group 4: B. schrammi and Group 5: B. peregrina), the same was identified in bPTP method. There is a range of Barcoding Gap between these analyzed sequences (Figure 9).

The GMYC model which combines algorithms that consider constant speciation rates and coalescence identified 9 differentiated clusters, being 1 cluster with the sequences of $B$. schrammi, 1 cluster with the sequences of $B$. peregrina, 1 cluster with 2 sequences of $B$. straminea, 1 cluster with the sequences of $B$. occidentalis and five differentiated clusters resulting from the partitioning of $B$. tenagophila sequences, besides 1 undifferentiated sequence of $B$. straminea (Figure 10). The higher Likelihhod Score (LR) of the GMYC model that splits the sequences into 9 clustres $(L R=1832.949)$ has a better fit on our data than for the null hypothesis, that considers that all the sequences belong to the same species ( $\mathrm{LR}=1367.263$ ).

The phylogenetic tree represented in Figure 10 shows high statistical support values for COI sequences, which come to an agreement with delimitation methods and the all specimens identified by morphology.

\section{Discussion}

\section{Morphological taxonomy}

Anatomical characters are the basis for identifying different species of the genus Biomphalaria. The shell and soft tissue structures, identified in the six studied taxa, are generally in accordance with the descriptions provided by Paraense (1966a, 1970, 1974, 1975, 1981) and Paraense et al. (1964). However, in our material, we observed morphological structures in the shell, mantle and vagina with different aspects from those available in the bibliography:

Table 4. Morphological characters with expressive anatomical specificities shared, exclusively, among Biomphalaria species. Total number of morphological characters considered $=26$.

\begin{tabular}{|c|c|c|c|c|c|}
\hline Morphological species & B. tenagophila & B. occidentalis & B. oligoza & B. peregrina & B. schrammi \\
\hline B. tenagophila & 26 & & & & \\
\hline B. occidentalis & 6 & 26 & & & \\
\hline B. peregrina & 1 & 0 & 1 & 26 & \\
\hline B. schrammi & 0 & 1 & 3 & 0 & 26 \\
\hline
\end{tabular}


Table 5. COI-Folmer gene polymorphism in Biomphalaria spp. and in the five species from the Upper Tietê River Basin, calculated in DnaSP. (N= number of sequences, $\mathrm{H}=$ number of haplotypes, $\mathrm{Hd}=$ haplotypic diversity and variance $(\mathrm{VHd}), \pi=$ average number of differences between two sequences, $\mathrm{K}=$ average number of differences).

\begin{tabular}{lccccc}
\hline Morphological species & N & H & Hd & $\boldsymbol{\pi}$ & K \\
\hline B. tenagophila & 106 & 6 & $0.52 \pm 0.05$ & 0.01 & 0.01 \\
B. straminea & 3 & 2 & 0.564 & 0.31 & 0 \\
B. occidentalis & 4 & 1 & 0 & 0 & 0 \\
B. peregrina & 5 & 1 & 0 & 0 & 0 \\
B. schrammi & 4 & 11 & $0.64 \pm 0.04$ & 0.03 & 16.34 \\
Biomphalaria spp. & 122 & & 0 & 0 \\
\hline
\end{tabular}

Table 6. Values of Kimura-2p genetic divergence calculated for the intra and interspecific species in the Upper Tietê River Basin.

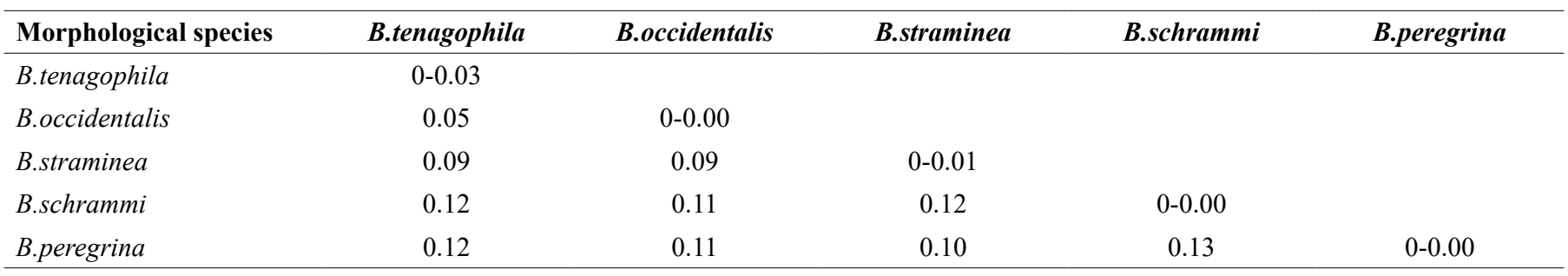

Table 7. Similarity indices between the $122 \mathrm{COI}$ sequences of the Biomphalaria obtained in this study, sequences provided by the Genbank and taxonomic molecular units (MOTUs) estimated following the ABGD, bPTP and GMYC methods. (NS= Number of Specimens, NH= Number of Haplotypes, NPS= Number of Putative Species).

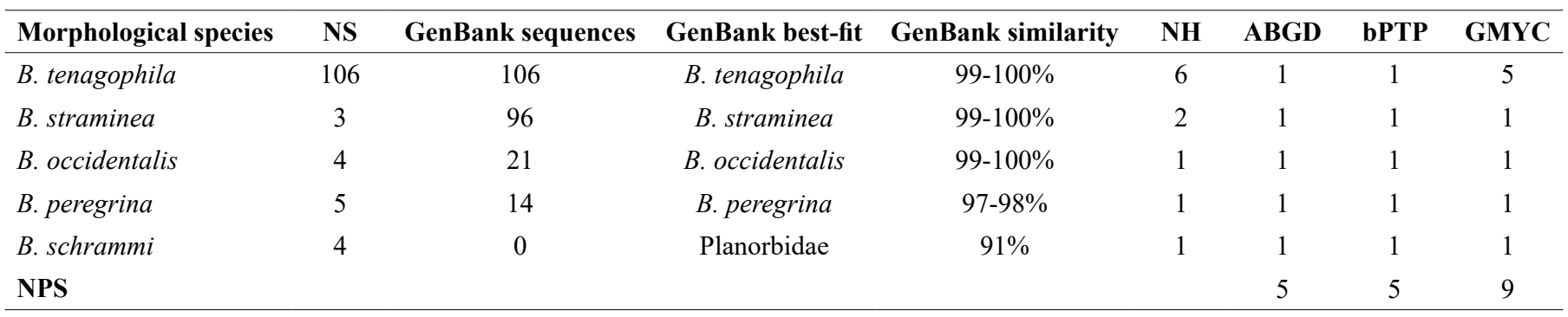

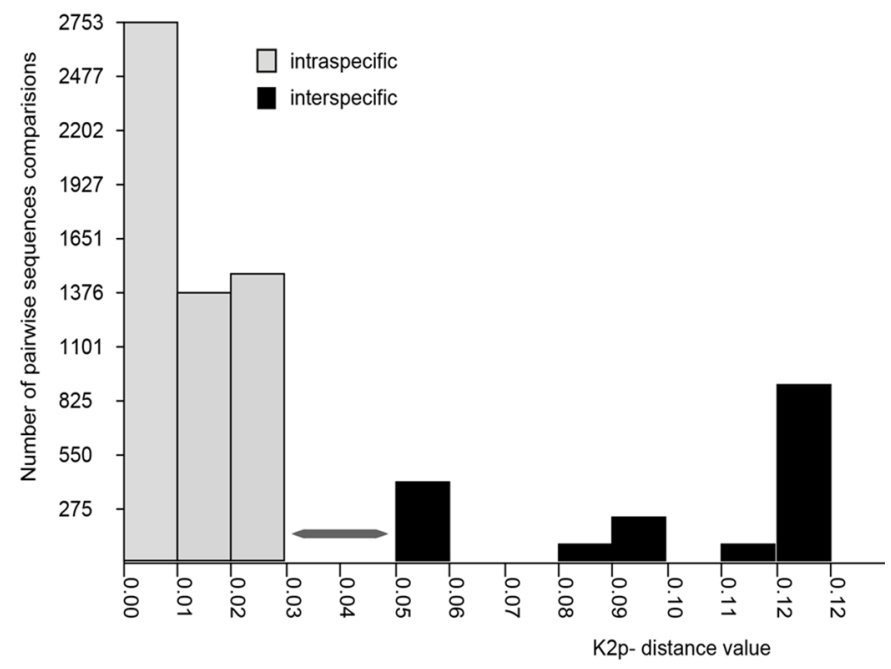

Figure 9. Frequency distribution of K2p-distances within the $122 \mathrm{COI}$ sequences as calculated by ABGD. Gap (-).

1- Biomphalaria schrammi with up to $4 \mathrm{~mm}$ shell diameter are characterized by Paraense (1975) with shells devoid of lamellae and openings directed forward, suggesting that the opening of the shell leans to the left only after the appearance of the lamellae. Unlike what is mentioned by Paraense (1975), in our material, we verified specimens of B. schrammi with shell diameter greater than $4 \mathrm{~mm}$, with and without lamellae, and the opening was deflected to the left in all of them (Figure 2).

Notwithstanding, we observed variation in the degree of deflection between shells with and without internal lamellae. In shells without lamellae, deviation is lower than in those that present lamellae. These are intra-population variations of $B$. schrammi that may be associated with a greater adaptation that some snail species present in the face of environmental adversity (Medeiros et al. 2015).

Nevertheless, we consider that the degree of deflection of the $B$. schrammi shell opening is visually stronger than in B. peregrina and $B$. straminea, in which the shell opening has a slight inclination, although it also faces to the left (Figure 2).

2-The diameter of the shell, according to Paraense (1970), is related to the pigmentation of the mantle. Adult individuals of species with greater shell diameter, such as B. tenagophila and B. occidentalis, have a homogeneous mantle pigmentation pattern differing from species of snails with smaller shell diameter, such as $B$. oligoza, $B$. peregrina, $B$. schrammi and $B$. straminea that have mantles with stains and punctuation at any age (Appendix 1). PAHO (1968) and Paraense (1966a, 1970, 1974) do not mention differences in the mantle pigmentation pattern of these last four species.

In our material, we observed that the pigmentation pattern of B. schrammi mantle is mostly with elongated patches transversely 


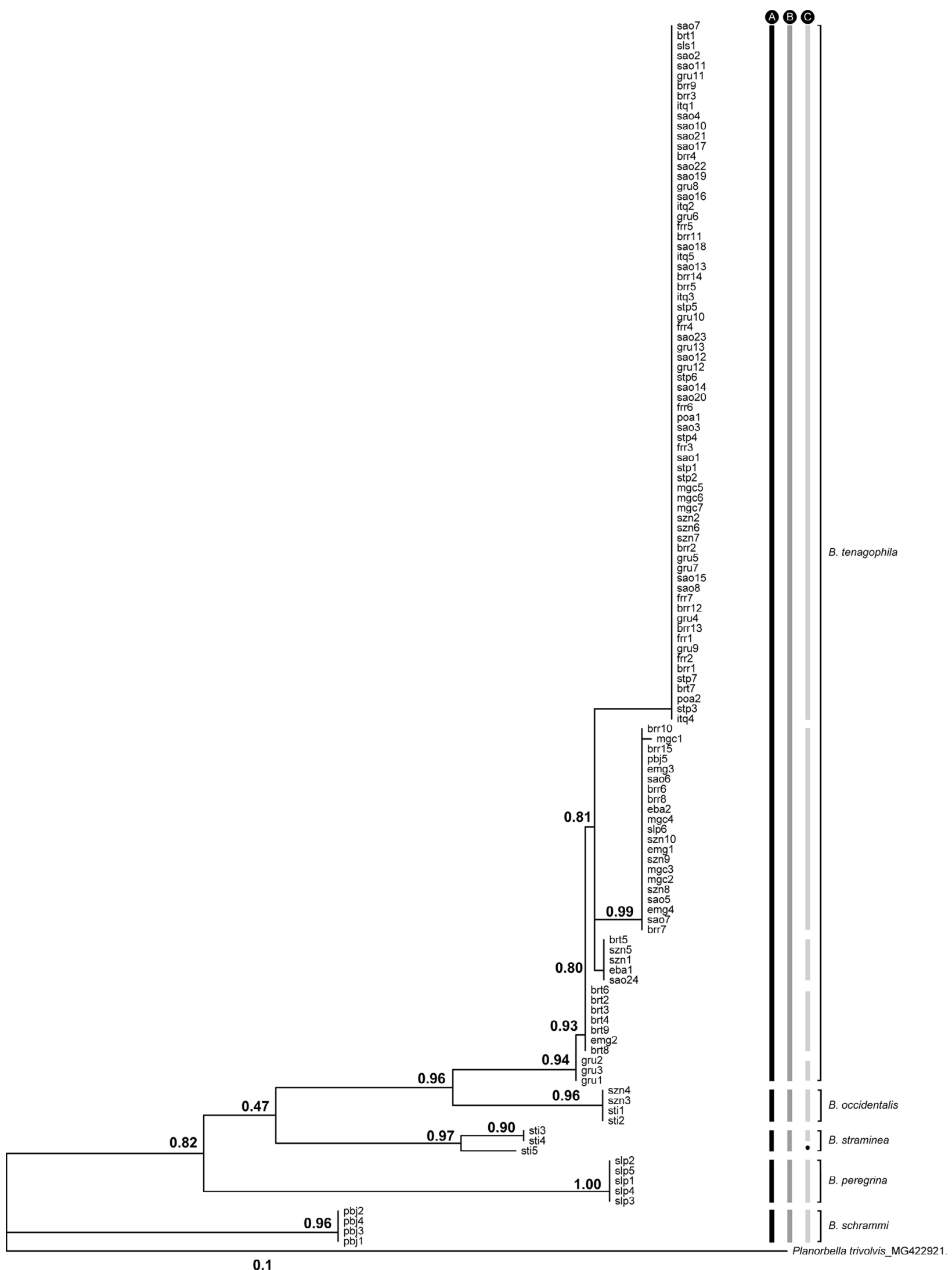

Figure 10. Maximum Likelihood phylogenetic tree of the 122 Biomphalaria COI sequences, plus one sequence of Planorbella trivolvis used as outgroup. Grey bars represent the putative species as inferred by ABGD distance-method (A) and tree-based methods bPTP (B) and GMYC (C). All 122 sequences are assigned to named taxa by morphology-based identification. The tree was constructed on PHYML based on GTR + I model and branch support values calculated by Shimodaira-Hasegawa [SH]-aL.RT. brr, Barueri; brt, Biritiba Mirim; eba, Embu das Artes; emg, Embu Guaçu; frr, Franco da Rocha; gru, Guarulhos; itq, Itaquaquecetuba; mgc, Mogi das Cruzes; pbj, Pirapora do Bom Jesus; poa, Poá; sao, São Paulo; slp, Salesópolis; sls, São Lourenço da Serra; sti, Santa Isabel; stp, Santana de Parnaíba; szn, Suzano. 
distributed on the mantle. This stain pattern gives the B. schrammi mantle a brindled appearance, which differs from the pattern presented by $B$. oligoza, B. peregrina and $B$. straminea, whose rounded or misshapen patches give the mantle a marbled appearance (Appendix 1).

3- The posterior region of the vagina has taxonomic relevance by the presence of a strongly corrugated area, as in $B$. straminea (Paraense 1975, 1988, Palasio et al. 2017), or a vaginal pouch, as in B. tenagophila, B. oligoza and B. peregrina (Paraense 1974, 1975, Paraense et al. 1964).

In our material, we observed a phenotypic difference as to the shape of the vaginal pouch, being possible to distinguish the bulged vaginal pouch of $B$. tenagophila (Figures 3 and 8 ) from the elongated vaginal pouch of B. oligoza (Figure 4) and B. peregrina (Figure 5). However, this difference is very subtle in young specimens, which may hinder the correct determination of the aforementioned species and, consequently, may generate false diagnoses.

Biomphalaria occidentalis (Figure 8B), like B. schrammi (Figure 6), has the posterior region of the smooth vagina, devoid of vaginal pouch or corrugated area (Paraense 1975, 1981, 1988).

Some specimens of $B$. occidentalis from Suzano presented a small and elongated dilatation on the ventral wall of the posterior region of the vagina (Figure $8 \mathrm{C}$ ) that is confused with the conspicuous vaginal pouch found in B. tenagophila (Figure 8A). Findings such as these were also observed by Paraense (1981) in B. occidentalis from Campo Grande, Mato Grosso do Sul. In this case, histological studies are needed to clarify the microanatomy of the posterior region of the vagina, as morphological variations within the same species can lead to diagnostic errors.

Biomphalaria oligoza, B. schrammi, B. straminea and $B$. tenagophila have inherent morphological characters to the taxa themselves. Already, the determining morphological characters to $B$. peregrina and $B$. occidentalis are common also to one or another of the other studied taxas.

The exclusive sharing of a larger number of morphological characters, with expressive anatomical specificities, as verified between $B$. tenagophila vs $B$. occidentalis (6/26 characters) and $B$. oligoza vs $B$. schrammi (3/26 characters), indicates that these are pairs of closest species. The closeness between $B$. tenagophila and $B$. occidentalis is expected, once both species are members of a complex. The common characters among the species of the two pairs make it difficult to delimit the taxas involved and, consequently, can generate false diagnoses.

This differed from what was observed in the relationships between other species (Table 4), which have low or zero amounts of morphological characters, with expressive anatomical specificities, common among paired species, showing that they are pairs whose species are better defined morphologically, with anatomical variations that may be intrinsically related to their evolutionary histories.

\section{Molecular taxonomy}

The molecular results are in agreement to specimens morphologically identified as $B$. occidentalis, B. peregrina, B. straminea and $B$. tenagophila. The COI-FOLMER sequences also obtained high similarity values in relation to the nominal species deposited in GenBank. In the case of $B$. schrammi, the sequences resulted in the lowest similarity value in the GenBank, which is why these sequences were identified in a supra-specific taxonomic group (Planorbidae Family). It is important to emphasize that, in relation to B. schrammi, the DNA Barcode sequences of this species obtained in our study are unique and unpublished in the GenBank.
In B. tenagophila, differences were found in relation to the statistical methods employed for the delimitation of MOTUs; ABGD and bPTP that gather the sequences of $B$. tenagophila in a single taxonomic unit, while in GYMC the sequences are divided into five molecular units (Figure 10). Among the three methods used, in GYMC the sampling, population size, and speciation rate are aspects that may interfere when estimating taxonomic molecular units (Fujisawa \& Barraclough 2013, Fontaneto et al. 2015). In the Upper Tietê River Basin, of the six Biomphalaria represented in this study, B. tenagophila is the most abundant species. The population size and the intraspecific diversity of $B$. tenagophila, represented by numerous mitochondrial haplotypes $(\mathrm{H}=6)$ herein (Table 5), are aspects that may have caused decreased accuracy of GYMC in comparison to ABGD and bPTP.

The statistical methods employed in this work by DNA Barcode determine, with robustness, the limits of each species belonging to the pairs aforementioned in the morphological study (B. tenagophila vs $B$. occidentalis). The maximum likelihood analysis recovered $B$. tenagophila and $B$. occidentalis in differentiated branches, with high values of statistical support, which indicates the high resolution potential of the phylogenetic analysis in the delimitation of these morphologically similar species. For that reason, in the case of B. tenagophila and $B$. occidentalis, molecular characters may be more resolutive in taxonomic terms than morphological taxonomy.

The pairs of species with the most significant degrees of morphological differentiation (B. tenagophila vs B. schrammi, $B$. tenagophila vs $B$. straminea, $B$. tenagophila vs $B$. peregrina, $B$. occidentalis vs $B$. peregrina, $B$. occidentalis vs $B$. straminea, $B$. occidentalis vs $B$. schrammi, $B$. straminea vs $B$. schrammi, $B$. straminea vs $B$. peregrina and $B$. schrammi vs $B$. peregrina) also have high genetic distance values (9 a 13\%) (Table 6). Their genetic divergence values are high enough to delimit these species by DNA Barcode (Hebert et al. 2013), indicating that this is an accurate molecular method for these species pairs.

\section{Morphological taxonomy integrated with molecular taxonomy in specific determination}

Traditional taxonomy, when associated with more sophisticated study methods, such as the use of molecular markers, makes diagnoses more consistent. Among the advantages of using the traditional taxonomy is the low cost, especially in areas with high species diversity and lack of financial resources for research, and the fact that the classification of species is fast, didactic, and understandable for people and professionals who have no prior knowledge of molecular methods (Barros 2015).

Using taxonomic surveys of freshwater organisms as reference, Stein et al. (2014) calculated that the total cost of identifying 200 molecular taxonomic units made by DNA barcode and Sanger sequencing is approximately 1.7 times greater than the cost of obtaining results through morphology.

The molecular approach is similar to the morphological approach when using delimitation methods for species based on distance (ABGD) and phylogeny (bPTP). Due to its high resolution in ABGD and BPTP, the DNA barcode has the potential to impart greater objectivity to the morphological identification and can be used as a control for the characterization of Biomphalaria species. The disparity between molecular and morphological results in GMYC is expected, because of a 
higher probability of coalescence of $B$. tenagophila and B. straminea in differentiated lineages over time and is therefore an important indicator of the evolutionary factors of these species.

In Biomphalaria, the number of COI sequences deposited in the GenBank is significantly higher for intermediate host species of the S. mansoni (Figure 11). The extension of the database in Genbank or BOLD with the insertion of COI sequences for all Biomphalaria species is fundamentally important to a solid analysis of the application limits of the molecular approach in the delimitation of taxonomic units.

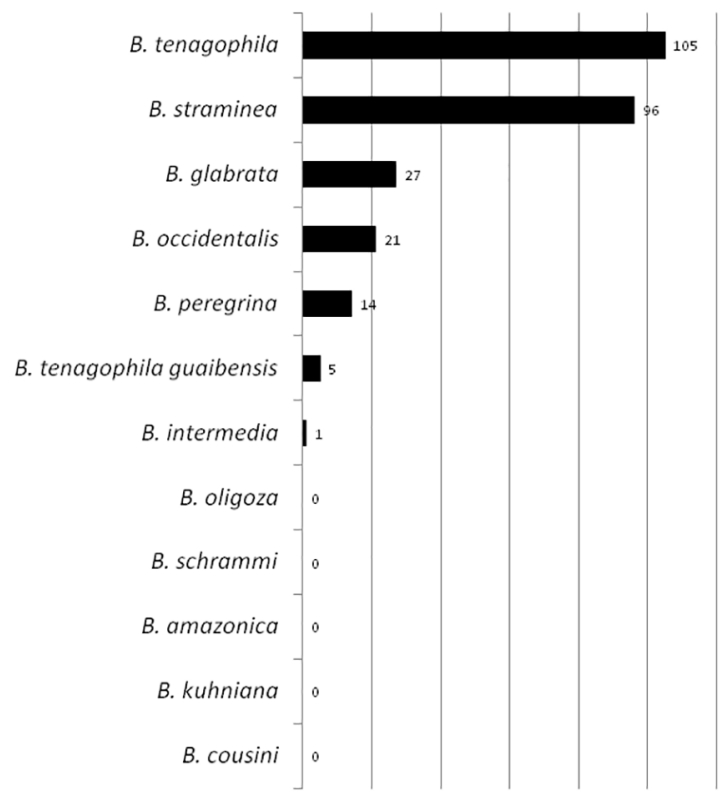

Figure 11. Number of partial sequences of the mitochondrial COI gene deposited in GenBank for different Biomphalaria species found in Brazil.

\section{Conclusions}

1. Our results show that the fundamental morphological characters in determining the six Biomphalaria studied relate to shell (shape of turns, shape and position of the opening, carenas and lamellae), to mantle (pigmentation pattern of the mantle and stains), and to the reproductive system, which has the greatest number of diagnostic characters, related to ovotest, seminal vesicle, oviduct pouch, vaginal pouch, vaginal corrugation, spermatheca duct, spermatheca, spermoduct, prostate and penial complex.

2. Biomphalaria oligoza, B. schrammi, B. straminea and B. tenagophila, which presented inherent morphological characters, are considered species with decisive characteristics for diagnostic classification of taxa. In contrast, specific determination of $B$. peregrina and $B$. occidentalis is based on a sum of morphological characters.

3. The high number of common morphological traits among the pairs of species $B$. tenagophila vs $B$. occidentalis and $B$. oligoza vs $B$. schrammi indicates that there is a close relationship between these taxa.

4. In the following pairs of species $B$. tenagophila vs B. oligoza, $B$. tenagophila vs $B$. schrammi, $B$. tenagophila vs $B$. straminea, $B$. tenagophila vs $B$. peregrina, $B$. occidentalis vs $B$. oligoza, $B$. occidentalis vs $B$. peregrina, $B$. occidentalis vs $B$. schrammi, $B$. occidentalis vs $B$. straminea, $B$. oligoza vs $B$. peregrina, $B$. oligoza vs $B$. straminea, $B$. peregrina vs $B$. schrammi, $B$. peregrina vs $B$. straminea and $B$. schrammi vs $B$. straminea, the low or nonexistent sharing of morphological characters indicates that the relationship between the taxa of each pair is weak.

5. Resoluteness and effectiveness are two of the critical characteristics of DNA Barcoding for taxonomic biodiversity studies in Biomphalaria. The use of DNA Barcoding combined with morphological taxonomy can help to solve some taxonomical problems, resulting in advantages to geographically extensive malacological surveys.

6. The presence of $B$. tenagophila, the intermediate host of $S$. mansoni in the hydrographic network of the Upper Tietê River Basin indicates that this region is a hot-spot for the transmission of schistosomiasis. The occurrence of $B$. peregrina and $B$. straminea in the Upper Tietê River Basin requires attention. The former is a potential intermediate host of $S$. mansoni (Paraense \& Corrêa 1973) and the latter an intermediate host of the parasite in nature (Paraense 2001). Biomphalaria straminea is the main intermediate host for $S$. mansoni in the northeast of Brazil (Figueiredo 1989, Ohlweiler et al. 2010). Its high capacity to spread through new water collections (Pointier et al. 2005, Palasio et al. 2019) may facilitate the expansion of the species in the state of São Paulo. This poses a challenge to control the disease, which requires monitoring and constant mapping of water bodies and the snails associated with them.

\section{Supplementary material}

The following online material is available for this article:

Appendix 1 - Pigmentation of the mantle. A, adult specimen of Biomphalaria tenagophila; B, young specimen of Biomphalaria tenagophila; C, Biomphalaria oligoza; D, Biomphalaria straminea; $\mathrm{E}$, adult specimen of Biomphalaria. occidentalis; F, young specimen of Biomphalaria occidentalis; G, Biomphalaria peregrina; $\mathrm{H}$, Biomphalaria schrammi.

Appendix 2 - Kidney tube of Biomphalaria tenagophila. A and $\mathrm{B}$, salience that runs obliquely along the kidney tube; $\mathrm{C}$, salience of the kidney tube in cross-section; D, smooth kidney tube. s, salience; $\mathrm{k}$, kidney tube.

\section{Acknowledgments}

The authors thank the field team from the Division of Special Programs of SUCEN for their collaboration in fieldwork, Daniela Brescovit for the final text revision, Ricardo Soares for the final layout of morphological illustrations and FAPESP for financial support (process number 2015/05719-9).

\section{Author Contributions}

Fernanda Pires Ohlweiler: Obtaining financial resources from Fapesp. Conceptual and design of the study. Collection, analysis and interpretation of morphological data. Preparation and critical review of the manuscript, including the morphological and molecular study. 
Thays de Jesus Rossignoli: Collection and analysis of morphological data. Extraction and amplification of genomic material to obtain COI sequences. Preparation of the manuscript.

Raquel Gardini Sanches Palasio: Performed the DNA Barcoding experiments. Analysis and interpretation of molecular data. Geospatial mapping. Preparation of the manuscript.

Roseli Tuan: Conceptual and practical framework for DNA Barcoding analysis, critical revision, adding intellectual content to molecular analysis.

\section{Conflicts of Interest}

The authors declare that they have no conflict of interest related to the publication of this manuscript.

\section{References}

ANISIMOVA, M., GIL, M., DUFAYARD, J.F., DESSIMOZ, C. \& GASCUEL, O. 2011. Survey of Branch Support Methods Demonstrates Accuracy, Power, and Robustness of Fast Likelihood-based Approximation Schemes. Syst. Biol.60: 685-699. https://doi.org/10.1093/sysbio/syr041.

BENSON, D.A., CAVANAUGH, M., CLARK, K., KARSCH-MIZRACHI, I., LIPMAN, D.I., OSTELL, J. \& SAYERS, E.W. 2012. GenBank. Nucleic Acids Res. 41 (D1): D36-D42. https://doi.org/10.1093/nar/gks1195.

BARACHO, M. 2013. Série Panorama das doenças negligenciadas: Nordestinos morrem mais em decorrência da esquistossomose. Determinantes Sociais de Saúde, Fiocruz. Available at: http://dssbr.org/site/2013/04/serie-panoramadas-doenças-negligenciadas-nordestinos-morrem-mais-em-decorrencia-daesquistossomose/. (last access on 05/12/2019).

BARROS, M.J.F. 2015. Diversidade taxonômica intraespecífica: como refinar a conservação biológica nos trópicos? Natureza on line. 13(1): 20-25.

BRASIL. Ministério da Saúde. Secretaria de Vigilância em Saúde. 2008. Vigilância e Controle de Moluscos de Importância Epidemiológica: Diretrizes Técnicas: Programas de Vigilância e Controle da Esquistossomose (PCE). $2^{\text {nd }}$ Edition. Brasília: Editora do Ministério da Saúde. p.178.

CALDEIRA, R.L., VIDIGAL, T., MATINELLA, L., SIMPSON, A.J.G. \& CARVALHO, O.S. 2000. Identification of planorbids from Venezuela by polymerase chain reaction amplification and restriction fragment length polymorphism of internal transcriber spacer of the RNA ribosomal gene. Mem. I. Os. Cr.95: 171-177. http://dx.doi.org/10.1590/S007402762000000200007 .

CARVALHO, O.S., JANNOTI-PASSOS, L.K. \& CALDEIRA, R.L. 2008. Importância Epidemiológica e biologia molecular aplicada ao estudo dos moluscos do gênero Biomphalaria. In Schistosoma mansoni e Esquistossomose: Uma Visão Multidiciplinar (O.S. Carvalho, P.M.Z. Coelho \&H.L. Lenz, eds). Fiocruz, Rio de Janeiro. p.311- 345.

COLLADO, G.A., VALLADARES, M.A. \& MÉNDEZ, M.A. 2016. Unravelling cryptic species of freshwater snails (Caenogastropoda, Truncatelloidea) in the Loa River basin, Atacama Desert. Syst. Biodivers. 14(4): 417-429. http:// dx.doi.org/10.1080/14772000.2016.1153526.

FIGUEIREDO, C.S.B. 1989. Interações entre espécies de Biomphalaria: Moluscos transmissores da esquistossomose no Nordeste Brasileiro. Master's Thesis, João Pessoa, Universidade do Paraíba.

FOLMER, O., BLACK, M., HOEH, W., LUTZ, R. \& VRIJENHOEK, R. 1994. DNA primers for amplification of mitochondrial cytocrome coxidase subunit I from diverse metazoan invertebrates. Mol. Mar. Biol. Biotech. 3(5): 292- 299.

FONTANETO, D., FLOT, J.F. \& TANG, C.Q. 2015. Guidelines for DNA taxonomy, with a focus on the meiofauna. Mar. Biodivers. 45(3): 433-451. https://doi.org/10.1007/s12526-015-0319-7.
FUJISAWA, T. \& BARRACLOUGH, T.G. 2013. Delimiting species using singlelocus data and the Generalized Mixed Yule Coalescent approach: a revised method and evaluation on simulated data sets. Syst. Biol. 62(5):707-724. https://doi.org/10.1093/sysbio/syt033.

GUINDON, S. \& GASCUEL, O. 2003. PhyML: A simple, fast, and accurate algorithm to estimate large phylogenies by maximum likelihood. Syst. Biol. 52(5): 696-704. https://doi.org/10.1080/10635150390235520.

HALL, T.A. 1999. BioEdit: a user-friendly biology sequence alignment editor and analysis program for windows 95/98/NT. Nucl. Acid. S. 41: 95-98.

HEBERT, P.D.N., CYWINSKA, A., BALL, S.L. \& DEWAARD, J.R. 2003. Biological identifications through DNA barcodes. Proc. R. Soc. Lond. 270: 313-321. https://doi.org/10.1098/rspb.2002.2218.

HEBERT, P.D.N., WAARD, J.R., ZAKHAROV, E.V., PROSSER, S.W.J., SONES, J.E., MCKEOWN, J.T.A., MANTLE, B. \& LA-SALLE J. 2013. A DNA Barcode Blitz: Rapid Digitization and Sequencing of a natural History Collection. Plos One. 8: e68535. https://doi.org/10.1371/journal. pone.0068535.

IBGE, Instituto Brasileiro de Geografia e Estatística. 2015. Malha Municipal 2015 (escala 1:250.000). Mapas, bases e referenciais, bases cartográficas, malhas digitais. Available at: https://mapas.ibge.gov.br/bases-e-referenciais/ bases-cartograficas/malhas-digitais.html(last access on 09/12/2019).

KATOH, K., ROSEWICKI, J. \&. YAMADA, K.D. 2017. MAFFT online service: multiple sequence alignment, interactive sequence choice and visualization. Brief. Bioinform. 20(4): 1160-1166.https://doi.org/10.1093/bib/bbx108.

KEANE, T.M., CREEVEY, C., PENTONY, M.M., NAUGHTON, T.J. \& MCLNERNEY, J.O. 2006. Assessment of methods for amino acid matrix selection and their use on empirical data shows that ad hoc assumptions for choice of matrix are not justified. BMC Evol. Biol. 6:29. https://doi. org/10.1186/1471-2148-6-29.

KUMAR, S., STECHER, G., LI, M., KNYAZ, C. \& TAMURA, K. 2018. MEGA X: Molecular Evolutionary Genetics Analysis across Computing Platforms. Mol. Biol. Evol. 35(6): 1547-1549. https://doi.org/10.1093/ molbev/msy096.

MEDEIROS, C., CALDEIRA, R.L., MENDONÇA, C.L., CARVALHO, O.S. \& D'ÁVILA, S. 2015. Ontogeny and morphological variability of shell in populations of Leptinaria unilamellata (d'Orbigny, 1835) (Mollusca, Pulmonata, Subulinidae). Springerplus. 4:191. https://doi.org/10.1186/ s40064-015-0959-x.

NCBI, National Center for Biotechnology Information, U.S. National Library of Medicine. GenBank ${ }^{\circledR}$. Available at: https://www.ncbi.nlm.nih.gov/genbank/ (last access on 28/11/2018).

OHLWEILER, F.P. \& ROSSIGNOLI, T.J. 2016. Biodiversidade das Biomphalaria (Mollusca, Planorbidae) na região metropolitana de São Paulo como complemento à carta planorbídica do estado de São Paulo. BEPA, Bol. Epidemiol. Paul. 13(152): 1-17. Available at: http://www.saude.sp.gov. $\mathrm{br} /$ coordenadoria-de-controle-de-doencas/ (last access on 09/12/2019).

OHLWEILER, F.P., TAKAHASHI, F.Y., GUIMARÃES, M.C.A., GOMES, S.R. \& KAWANO, T. 2010. Manual de Gastrópodes Límnicos e Terrestres do Estado de São Paulo Associados às Helmintoses. Porto Alegre: Redes.p.224.

OHLWEILER, F.P., EDUARDO, J.M., TAKAHASHI, F.Y., CREIN, G.A., LUCCA, L.R. \& OLIVEIRA, R.C. 2013. Larvas de trematódeos associadas a moluscos de água doce em municípios da Região Metropolitana de São Paulo, Estado de São Paulo, Brasil. Rev. Pan-Amazonica. 4(3): 37-48. http:// dx.doi.org/10.5123/S2176-62232013000300006

PALASIO, R.G.S., GUIMARÃES, M.C.A., OHLWEILER, F.P. \& TUAN, R. 2017. Molecular and morphological identification of Biomphalaria species from the state of São Paulo, Brazil. Zookeys. 668: 11-32. https:// doi.org/10.3897/zookeys.668.10562.

PALASIO, R.G.S., ROSA-XAVIER, I.G., CHIARAVALLOTI-NETO, F. \& TUAN, R. 2019. Diversity of Biomphalaria spp. freshwater snails and associated mollusks in areas with schistosomiasis risk, using molecular and spatial analysis tools. Biota Neotrop. 19(4): e20190746. http://dx.doi. org/10.1590/1676-0611-BN-2019-0746. 
PAHO, Pan American Health Organization. 1968. A guide for the identification of the snails intermediate hosts of schistosomiasis in the Americas. WashingtonUSA: Pan American Sanitary Bureau, Regional Office of the World Health Organization, p.122.

PARAENSE, W.L. 1966a. The synonymy and distribution of Biomphalaria peregrina in the Neotropical Region. Rev. Bras. Biol. 26: 269-296.

PARAENSE, W.L. 1966b. Biomphalaria amazonica and Biomphalaria cousini, two new species of neotropical planorbids molluscs. Rev. Bras. Biol. 26(2): 115-126.

PARAENSE, W.L. 1970. Planorbídeos hospedeiros intermediários do Schistosoma mansoni. In Esquistossomose Mansoni (E.S. Cunha, ed.). Sarvier/Edusp Universidade de São Paulo, São Paulo, $19^{\text {th }}$ edition. p.13-30.

PARAENSE, W.L. 1974. Biomphalaria oligoza $\mathrm{nn}$. for Tropicorbis phillipianus (Dunker) Sensu Lucena. Rev. Bras. Biol. 34(3): 379-386.

PARAENSE, W.L. 1975. Estado atual da sistemática dos planorbídeos brasileiros. Arch. Mus. Nac. (Rio de J.). 55: 105-28.

PARAENSE, W.L. 1981. Biomphalaria occidentalis sp. n. from South America (Mollusca: Basommatophora: Pulmonata). Mem. I. Oswaldo Cruz. 76(2): 199-211.

PARAENSE, W.L. 1988. Biomphalaria kuhniana (Clessin, 1883), planorbid mollusc from south America. Mem. I. Oswaldo Cruz. 83(1): 1-12. http:// dx.doi.org/10.1590/S0074-02761988000100001.

PARAENSE, W.L. 2001. The schistosome vectors in the Americas. Mem. Inst. Oswaldo Cruz 96(suppl.): 7-16. https://doi.org/10.1590/S007402762001000900002.

PARAENSE, W.L. \& CORREAA, L.R. 1973. Susceptibility of Biomphalaria peregrina from Brazil and Ecuador to two strains of Schistosoma mansoni. Rev. Inst. Med. Trop. S. Paulo 15(3): 127-130.

PARAENSE, W.L. \& CORRÊA, L.R. 1978. Differential susceptibility of Biomphalaria tenagophila populations to infection with a strain of Schistosoma mansoni. J. Parasitol. 64(5): 822-826. https://www.jstor.org/ stable/3279509.

PARAENSE, W.L. \& DESLANDES, N. 1962. Australorbis intermedius $\mathrm{sp} . \mathrm{n}$. from Brazil. Rev. Bras. Biol. 22: 343-350.

PARAENSE, W.L., IBANEZ, H.N. \& MIRANDA, C.H. 1964. Australorbis tenagophilus in Peru, and its susceptibility to Schistosoma mansoni. Am. J. Trop. Med. Hyg. 13(4): 534-540. https://doi.org/10.4269/ajtmh.1964.13.534.

PIZA, J.T., RAMOS, A.S., MORAES, L.V.C., CORREA, R.R., TAKAKU, L. \& PINTO, A.C.M. 1972. Carta Planorbídica do Estado de São Paulo. Secretaria de Estado da Saúde, Campanha de Combate à Esquistossomose, CACEsq, sd,p.1-20.

PUILLANDRE, N., LAMBERT, A., BROUILLET, S. \& ACHAZ, G. 2012.ABGD, Automatic Barcode Gap Discovery for primary species delimitation. Mol. Ecol. 21(8): 1864-1877. https://doi.org/10.1111/j.1365-294X.2011.05239.x.

POINTIER, J.P., DAVID, P. \& JARNEA, P. 2005. Biological invasions: the case of planorbid snails. J. Helminthol. 79:249-256, 2005. https://doi. org/10.1079/JOH2005292.

QGIS Development Team. 2019. QGIS Version 3.4.11. Geographic Information System. Open Source Geospatial Foundation Project. Available at: http:// www.qgis.org/ (last access on 09/12/2019).

ROZAS, J., FERRER-MATA, A., SÁNCHEZ-DELBARRIO, J.C., GUIRAORICO, S., LIBRADO, P., RAMOS-ONSINS, S.E. \& SÁNCHEZ-GRACIA. 2017. A. DnaSP 6: DNA Sequence Polymorphism Analysis of Large Datasets. Mol. Biol. Evol. 34(12): 3299-3302. https://doi.org/10.1093/ molbev/msx248.
SHIMODAIRA, H. \& HASEGAWA, M. 1999. Multiple comparisons of log-likelihoods with applications to phylogenetic inference. Mol. Biol. Evol. 16(8): 1114-1116.

SILVA, C.A. 2012. Avaliação e retificação específica de moluscos do gênero Biomphalaria Preston, 1910 do acervo da Coleção de Malacologia Médica (Fiocruz-CMM). Master's Thesis, Programa de Pós-Graduação em Ciências da Saúde. Centro de Pesquisas René Rachou. Fundação Oswaldo Cruz. Ministério da Saúde. Belo Horizonte-MG. p.104.

SMA. Secretaria de Meio Ambiente do Estado de São Paulo. 2013. Rede de drenagem do estado de São Paulo obtida a partir da base do gisat (cartas topográficas na escala 1:50.000) por processo automático - coordenadoria de planejamento ambiental. Secretaria de Meio Ambiente do Estado de São Paulo. Available at: http://www.ambiente.sp.gov.br/cpla/mapa-da-rede-dedrenagem-do-estado-de-sao-paulo/ (last access on 09/12/2019).

SPATZ, L., VIDIGAL, T.H.D.A., CALDEIRA, R.L., NETO, E.D., CAPPA, S.M.G. \& CARVALHO, O.S. 1999. Study of Biomphalaria tenagophila tenagophila, Biomphalaria tenagophila guaibensis and Biomphalaria occidentalis by polymerase chain reaction amplificatiom and restriction enzyme digestion of the ribosomal RNA intergenic spacer regions. J. Mollus. Stud. 65(2): 143-149.

STEIN, E.D., MARTINEZ, M.C., STILES, S., MILLER, P.E. \& ZAKHAROV, E.V. 2014. Is DNA barcoding actually cheaper and faster than traditional morphological methods: results from a survey of freshwater bioassessment efforts in the United States? Plos One. 9: e95525. https://doi.org/10.1371/ journal.pone.0095525.

TUAN, R., OHLWEILER, F.P., PALASIO, R.G.S., ZANNA, R.D. \& GUIMARAES, M.C.A. 2012. Pattern of genetic divergence of Mitochondrial DNA sequences in Biomphalaria tenagophila complex species based on Barcode and morphological analysis. In Schistosomiasis (M.B. Rokni, eds). Intech, p.293-309. http://dx.doi.org/10.5772/25550.

VIDIGAL, T.H.D.A., CALDEIRA, R.L., SIMPSON, A.J.G. \& CARVALHO, O.S. 2000a. Further studies on the molecular systematic of Biomphalaria snails from Brazil. Mem. I. Oswaldo Cruz. 95(1): 57-66. http://dx.doi. org/10.1590/S0074-02762000000100009.

VIDIGAL, T.H.D.A., KISSINGER, J.C., CALDEIRA, R.L., PIRES, E.C.R., MONTEIRO, E., SIMPSON, A.J.G. \& CARVALHO, O.S. 2000b. Phylogenetic relationships among Brazilian Biomphalaria species (Mollusca: Planorbidae) based upon analysis of ribosomal ITS2 sequences. Parasitology. 121(6): 611-620. https://doi.org/10.1017/S0031182000006831.

ZHANG, J., KAPLI, P., PAVLIDIS, P. \& STAMATAKIS, A. 2013. A general species delimitation method with applications to phylogenetic placements. Bioinformatics. 29(22): 2869-2876. https://doi.org/10.1093/bioinformatics/ btt499.

ZHANG, J. 2015. Species Delimitation Server. Web interface for single and multiple threshold GMYC The Exelixis Lab, Scientific Computing Group, Heidelberg Institute for Theoretical Studies. Available at: http://species.h-its. org/gmyc/ (last access on 09/12/2019). 